\title{
Percutaneous Coronary Intervention in Elderly Patients with Coronary Chronic Total Occlusions: Current Evidence and Future Perspectives
}

This article was published in the following Dove Press journal:

Clinical Interventions in Aging

\author{
Lei Guo (iD) \\ Hai-Chen Lv (iD ${ }^{\prime}$ \\ Rong-Chong Huang ${ }^{2}$ \\ 'Department of Cardiology, The First \\ Affiliated Hospital of Dalian Medical \\ University, Dalian, People's Republic of \\ China; ${ }^{2}$ Department of Cardiology, \\ Capital Medical University Affiliated \\ Beijing Friendship Hospital, Beijing, \\ People's Republic of China
}

\begin{abstract}
The proportion of the elderly in the total population of the world is growing, and the number of elderly patients with coronary chronic total occlusions (CTO) is huge. The elderly patients often have more extensive coronary artery disease, more severe ischemic burden and higher risk of cardiovascular events, as compared to younger patients, and thereby they might greatly benefit from coronary revascularization, even though they may have higher risk of operative complications. Most interventional cardiologists are more likely to be reluctant to operate complex percutaneous coronary intervention (PCI) in elderly patients. The latest refinements in dedicated CTO-PCI equipment and techniques have led to high rates of success and low complications rates and have made the CTO-PCI procedures safe and effective among the elderly patients. However, up to now, there is no widely recognized consensus or guideline on treatment strategy of elderly CTO patients, and the prognosis in this population is unknown. In this review, we aim to provide an overview of the current evidence and future perspectives on PCI in elderly patients with CTOs.
\end{abstract}

Keywords: coronary chronic total occlusions, elderly, percutaneous coronary intervention

\section{Introduction}

A coronary chronic total occlusion (CTO) is defined as a complete occlusion of coronary artery with thrombolysis in myocardial infarction (TIMI) flow 0 for more than 3 months duration, and it remains one of the major challenging obstacles in coronary intervention. ${ }^{1,2}$ Coronary CTOs are commonly encountered during coronary angiography, with a prevalence ranging widely from $18-52 \%$ in patients with coronary artery disease (CAD). ${ }^{3,4}$ However, in the National Cardiovascular Disease Registry (NCDR) CathPCI registry, percutaneous coronary intervention (PCI) of CTO lesions comprises only accounts for $3.8 \%$ of attempted PCI cases. ${ }^{5}$ Recent data from the Canadian multi-center CTO registry indicates that only $10 \%$ CTOs were referred for PCI. ${ }^{3}$ The presence of CTO was associated with adverse cardiac outcomes and increased mortality in selected populations. In recent years, the latest improvements in dedicated CTO-PCI devices and techniques have led to high rates of success and low complications rates in experienced CTO centers. ${ }^{6-8}$ This evolution has contributed to an interest in CTO-PCI procedures and the increase in the number of CTO recanalizations, even complex lesions. ${ }^{9}$

In recent years, life expectancy is increasing and the proportion of older people in the world's total population is increasing. Elderly patients are regularly with 
a higher prevalence of complex CAD and other comorbidities. ${ }^{10}$ The prevalence of CTO increases with age, the number of elderly patients with CTOs is huge. ${ }^{11}$ However, nowadays, elderly patients are often excluded from randomized trials or registries related to CTO. The American Heart Association guidelines assign CTO-PCI a class IIa indication: reasonable in patients with appropriate clinical indications and performed by operators with appropriate expertise. ${ }^{12}$ Nevertheless, up to now, no widely recognized consensus or guideline on treatment strategy of elderly CTO patients, and the prognosis in this population is unknown. In this review, we aim to provide an overview of the current evidence and future perspectives on PCI in elderly patients with CTOs.

\section{PCI Is Avoided in Elderly Patients}

Numerous studies indicate that elderly patients are less likely to be referred for invasive coronary angiography than younger patients and older patients often have a low rate of revascularization in clinical practice. ${ }^{13,14}$ Previous trials showed advanced age was associated with higher rates of PCI-related complications and in-hospital adverse outcomes, as well as worse short-term prognosis. ${ }^{15,16}$ A study from National Cardiovascular Network database, Batchelor et al compared the outcomes of octogenarians receiving PCI with younger patients, and found that octogenarians had a 2 to 4-fold increased risk of complications, including death, stroke, Q wave myocardial infarction (MI) and kidney injury as compared to younger patients. In addition, octogenarian's mortality rate changed nearly 10 -fold and was strongly affected by comorbidities $(0.79 \%$ for non-risk factors vs $7.2 \%$ with renal insufficiency or left ventricular ejection fraction (LVEF) $<35 \%$ ). ${ }^{17}$ For the reasons that, elderly patients who require revascularization are more often with complex, multivessel disease which need more-challenging multi-lesion interventions than young patients (50\% vs $30 \%) .{ }^{18}$ With the aging process, coronary arteries of older patients are more likely to be tortuosity, have severe calcification, and total occlusion. ${ }^{19,20}$ Tortuous vessels increase the degree of difficulty in deployment of coronary devices and the risk of periprocedural complications. ${ }^{17}$ In a study from the Cardiovascular Health study, electron beam tomography was carried out to estimate coronary artery calcium in elderly patients, and Newman et al found increase in age by each year was associated with increased risk of coronary calcification score by $11 \% .{ }^{21}$ Intervention on calcified lesion are often associated with decreased technical and procedural success rates, increased periprocedural complications and restenosis rates cause by inadequate stent expansion.

Elderly patients are often with frailty which means decreased nutrition, physical functional decline, and reduced physical resistance to stressors. ${ }^{22}$ Frailty has been reported in $20 \%$ and more than $25 \%$ in patients aged $\geq 65$ and $\geq 85$ years respectively undergoing coronary revascularization. ${ }^{23,24}$ Frail patients had more comorbidities and more frequent left main or multivessel disease, but lower Seattle Angina Questionnaire scores for quality of life (ie poorer health status) compared with non-frail patients. ${ }^{25}$ Sánchez et al reported frailty are associated with higher rate of mortality, poorer in-hospital and postdischarge functional and adverse outcomes in CAD patients. ${ }^{26,27}$ Some easy measures can be taken to assess frailty, such as questionnaires, gait speed and handgrip strength. ${ }^{28,29}$

Multiple physiological changes might affect the outcome with PCI. Vascular stiffness, endothelial repair following injury and myocardial diastolic function are impaired with aging, which leads to systolic hypertension, negative vascular remodeling in response to injury and decreased left ventricular function. ${ }^{30}$ In addition, vascular injury and faulty repair, which are pathobiological construct of age-related thrombosis, result in sudden cardiac death, MI and ischemic stroke. ${ }^{31}$

\section{PCI in Elderly Patients with CTOs}

In the HORIZONS-AMI trial based on 3283 patients with ST-segment elevation myocardial infarction (STEMI) undergoing primary $\mathrm{PCI}$, it was reported that the presence of a CTO in non-infarct artery was an independent predictor of mortality. ${ }^{32}$ Although CTOs are more common in older patients, and CTO-PCI is less common in older patients compared to younger patients. ${ }^{13}$

Many CTO patients did not present typical angina,${ }^{33}$ and this situation was more likely to be on elderly CTO patients, owing to decreased physical activity and oxygen demand. ${ }^{34}$ Therefore, this makes them hard to be referred to clinicians and decrease the possibility of CTO-PCI. ${ }^{13}$ Moreover, elderly patients are often with multiple comorbidities, including anemia, chronic kidney insufficiency and heart failure, ${ }^{10,35}$ which also increase the risks related to CTOPCI. Elderly patients with CTOs present a challenge for most interventional cardiologists to perform PCI. Most interventional cardiologists are more likely to reluctant to operate complex PCI in elderly patients for the perception 
of poor prognosis in such high-risk subjects. Despite the lesional complexities and multiple comorbidities, Tanaka et al reported the overall technical success rate of CTO-PCI was achieved in $77 \%$ of the older patients and $79 \%$ of the younger patients $(\mathrm{P}=0.66)$, and a comparison between the successful and failed PCI patients showed a significantly superior three years cardiac survival $(97.6 \%$ vs $76.9 \%$, $\mathrm{P}=0.005) .{ }^{36}$ In a study consisting of 409 age $\geq 75$ years patients in Germany showed success rate of CTO-PCI was achieved in 307 (75\%) patients. After multivariate analysis, successful CTO-PCI significantly improve survival (adjusted hazard ratio [HR] 0.58, 95\% confidence interval [CI] $0.39-0.87, \mathrm{P}=0.009$ ) in the elderly. ${ }^{37}$ In a registry study including 356 patients (age $\geq 75$ years, $n=95$; aged $<75$ years, $\mathrm{n}=263$ ) who underwent CTO-PCI, procedural success rate of elderly patients was similar with the young (older vs younger patients: $74.3 \%$ vs $78.2 \%, \mathrm{P}=0.41$ ). ${ }^{35}$ Rate of major adverse cardiovascular events (MACE), a composite of death, cardiogenic shock, acute coronary syndrome (ACS) or repeated revascularization, at 20 months, was significantly reduced when elderly patients had undergone a successful CTO revascularization compared to failed CTO-PCI (HR 0.43, 95\% CI 0.19-0.96, $\mathrm{P}=0.039)$. Hoebers et al reported that $213(12 \%)$ patients in their cohort study which included 1791 patients were older than 75 years. ${ }^{38}$ Procedural success rates in elderly patients were not different compared to young patients (63.8\% vs $69.1 \%, \mathrm{P}=0.12)$. After 5 years follow-up, MACE rates were significantly reduced after successful PCI, compared to failed procedures $(25.8 \%$ vs $42.3 \%$, $\mathrm{P}<0.01)$ in the elderly, mainly driven by a significantly a reduction in coronary artery bypass grafting (CABG) $(0.0 \%$ vs $20.4 \%, \mathrm{P}<0.01)$. However, no significant differences were observed with respect to death $(19.6 \%$ vs $24.6 \%$, $\mathrm{P}=0.13)$ and $\mathrm{MI}(11.5 \%$ vs $8.0 \%, \mathrm{P}=0.87)$. Similarly, a single-center registry analyzing 120 patients whose age $\geq 75$ years, these elderly CTO patients who underwent successful CTO-PCI had a similar rate of 3-year cardiac mortality compared to unopened CTOs $(15.0 \%$ vs $16.0 \%$, $\mathrm{P}=1.000$ ). Furthermore, regarding the combined occurrences of hospitalization including angina, heart failure, reinfarction and repeat revascularization, no significant differences were observed between successful CTO-PCI and attempted CTO-PCI (10.0\% vs $17.0 \%, \mathrm{P}=0.657 ; 12.5 \%$ vs.17.1\%, $\mathrm{P}=0.547) .{ }^{13}$ Table 1 summarizes the recent studies assessing primary CTO-PCI in elderly patients. Successful rates of CTO-PCI among elderly and young patients are summarized in Figure 1.
According to the multicenter CTO registry from Japan, which contained $12 \%$ of the elderly patients whose age were $\geq 80$ years, reported that considering the actual incidence of the procedural success rate and related adverse events, invasiveness and the potential risks CTO-PCI might be acceptable in most cases. ${ }^{39}$

\section{PCI versus CABG in Elderly Patients with CTOs}

As mentioned, elderly CTO patients are more often to have left main disease, 3-vessel disease and a higher syntax score than non-elderly CTO patients that may need surgical revascularization. ${ }^{13,35}$ Complete revascularization is more frequently achieved with $\mathrm{CABG}$ rather than PCI. ${ }^{40}$ In the SYNTAX trial, a CTO was the main reason for incomplete revascularization, and the lower complete revascularization rate in the PCI arm was associated with increased MACE compared with $\mathrm{CABG}^{41}$ In a study of 2000 patients with multivessel disease from New York State's Percutaneous Coronary Interventions Reporting System, Hannan et al found those who had incomplete revascularization with a CTO had significantly higher mortality. $^{42}$

However, until now, there is no randomized control trial comparing PCI and CABG in elderly patients. It has been reported that patients with complex multivessel disease and diabetics could get more survival benefit from CABG in patients aged $\leq 65$ years. $^{43,44}$ A data including 73 consecutive patients aged $\geq 80$ years who underwent CABG between 1996 and 2001 showed quality of life could be elevated by CABG. ${ }^{45}$ In a meta-analysis of 66 studies in patients aged $\geq 80$ years who underwent coronary revascularization, a greater number of patients with multivessel disease and male patients were treated with CABG than with PCI and showed 30-day mortality and 1-year survival were similar between CABG and PCI. ${ }^{46}$ Similar results have been found by Hannan et al, who reported the results of New York State's registries for CABG and for PCI. ${ }^{42}$ In this study, a total of 3864 patients receiving drug-eluting stent (DES) and CABG (1932 CABG-DES pairs) with multivessel disease were analyzed and three outcomes (mortality, stroke/MI/mortality and repeat revascularization) at 2.5 years were compared. The rates of mortality (DES/CABG HR 1.06, 95\% CI 0.87-1.30) and stroke/MI/mortality (DES/CABG HR 1.15, 95\% CI 0.97-1.38) for the two procedures were similar. ${ }^{47}$ Hlatky et al pooled individual patient data from 
Table I Recent Studies of CTO-PCI in Elderly Patients

\begin{tabular}{|c|c|c|c|c|c|c|}
\hline Study & $\begin{array}{l}\text { Age } \\
\text { (Years) }\end{array}$ & Number & $\begin{array}{l}\text { Successful } \\
\text { Rate }\end{array}$ & $\begin{array}{l}\text { Follow- } \\
\text { Up } \\
\text { (Years) }\end{array}$ & Complication Rates & Clinical Outcomes \\
\hline $\begin{array}{l}\text { Guo } \\
\text { et } \mathrm{al}^{66}\end{array}$ & $\begin{array}{l}\geq 65 \\
<65\end{array}$ & $\begin{array}{l}630 \\
664 \\
\geq 65 \mathrm{PCIN}=209 \\
\geq 65 \mathrm{MT} \mathrm{N}=421\end{array}$ & NA & 3.6 & $\begin{array}{l}\text { Myocardial infarction, } \\
0.5 \% \text {; } \\
\text { Coronary dissection, } \\
2.9 \% \\
\text { Coronary perforation, } \\
1.4 \%\end{array}$ & $\begin{array}{l}\geq 65 \text { years } \\
\text { MT vs successful PCl: cardiac mortality }(9.3 \% \\
\text { vs } 5.0 \%, P=0.378), \text { MACE }(28.3 \% \text { vs } 15.1 \% \text {, } \\
P=0.070), \text { MI }(9.0 \% \text { vs } 3.7 \%, P=0.097), \text { TVR } \\
(14.5 \% \text { vs } 9.0 \%, P=0.592)\end{array}$ \\
\hline $\begin{array}{l}\text { Flores- } \\
\text { Umanzor } \\
\text { et } \mathrm{al}^{50}\end{array}$ & $\begin{array}{l}\geq 75 \\
<75\end{array}$ & $\begin{array}{l}328 \\
924 \\
\geq 75 \text { PCI N=53 } \\
\geq 75 \text { MT N=233 } \\
\geq 75 \text { CABG N=42 }\end{array}$ & NA & 3.5 & $\begin{array}{l}\text { Myocardial infarction, } \\
2 \% ; \\
\text { Cardiac tamponade, } 2 \% ;\end{array}$ & $\begin{array}{l}\geq 75 \text { years } \\
\text { MT vs } \mathrm{PCl} \text { vs CABG: all-cause mortality } \\
(54 \% \text { vs } 32 \% \text { vs } 19 \%, \mathrm{P}<0.00 \mathrm{I}) \text {, cardiac } \\
\text { mortality ( } 38 \% \text { vs } 17 \% \text { vs } 19 \%, \mathrm{P}=0.002) \text {, } \\
\text { acute } \mathrm{MI}(12 \% \text { vs } 8 \% \text { vs } 5 \%, \mathrm{P}=0.2)\end{array}$ \\
\hline $\begin{array}{l}\text { Toma } \\
\text { et } \mathrm{al}^{37}\end{array}$ & $\begin{array}{l}\geq 75 \\
<75\end{array}$ & $\begin{array}{l}409 \\
1593 \\
\geq 75 \text { successful } \mathrm{PCl} \\
\mathrm{N}=307 \\
\geq 75 \text { failed } \mathrm{PCl} \\
\mathrm{N}=102\end{array}$ & $\begin{array}{l}75.1 \% \\
85.1 \%\end{array}$ & 2.6 & $\begin{array}{l}\text { Myocardial infarction, } \\
0.5 \% \text {; } \\
\text { Coronary perforation, } \\
0.5 \% \text {; } \\
\text { Cerebrovascular } \\
\text { accident, } 0.2 \% \text {; } \\
\text { Major bleeding, } 2.4 \% \text {; } \\
\text { Vascular complication, } \\
0.7 \%\end{array}$ & $\begin{array}{l}\geq 75 \text { years } \\
\text { successful vs failed } \mathrm{PCl} \text { : all-cause mortality } \\
\text { (adjusted HR } 0.58,95 \% \mathrm{Cl} 0.39-0.87, \\
\mathrm{P}=0.009 \text { ), } \mathrm{MACE} \text { (adjusted HR } 0.84,95 \% \mathrm{Cl} \\
0.59-1.20, \mathrm{P}=0.34 \text { ) }\end{array}$ \\
\hline $\begin{array}{l}\text { André } \\
\text { et } \mathrm{al}^{35}\end{array}$ & $\begin{array}{l}\geq 75 \\
<75\end{array}$ & $\begin{array}{l}93 \\
263 \\
\geq 75 \text { successful } \mathrm{PCl} \\
\mathrm{N}=7 \mathrm{I} \\
\geq 75 \text { failed } \mathrm{PCl} \\
\mathrm{N}=22\end{array}$ & $76.3 \%$ & 1.7 & $\begin{array}{l}\text { Myocardial infarction, } \\
3.2 \% \text {; } \\
\text { Acute renal failure, } 4.3 \% \\
\text { CABG, } 2.2 \%\end{array}$ & $\begin{array}{l}\geq 75 \text { years } \\
\text { successful vs failed } \mathrm{PCl} \text { : } \text { mortality }(2 \mathrm{I} . \mathrm{I} \% \text { vs } \\
9.1 \%, \mathrm{P}=0.34), \mathrm{MI}(2.8 \% \text { vs } 18.2 \%, \mathrm{P}=0.026) \text {, } \\
\text { unstable angina }(\mathrm{I} .4 \% \text { vs } 4.5 \%, \mathrm{P}=0.42), \mathrm{PCl} \\
(2.8 \% \text { vs } 22.7 \%, \mathrm{P}=0.007)\end{array}$ \\
\hline $\begin{array}{l}\text { Lee } \\
\text { et } \mathrm{al}^{65}\end{array}$ & $\begin{array}{l}\geq 75 \\
<75\end{array}$ & $\begin{array}{l}311 \\
1709 \\
\geq 75 \\
\text { revascularization } \\
N=158 \\
\geq 75 \text { MT N=153 }\end{array}$ & $79.1 \%$ & 2.8 & NA & $\begin{array}{l}\geq 75 \\
\text { MT vs revascularization: cardiac mortality } \\
(\mid 9.6 \% \text { vs } 10.8 \%, P=0.27), \text { MACE }(26.1 \% \text { vs } \\
\mid 8.4 \%, P=0.76), M I(5.2 \% \text { vs } 2.5 \%, P=0.54) \text {, } \\
\text { repeat revascularization }(8.5 \% \text { vs } 8.2 \% \text {, } \\
P=0.85)\end{array}$ \\
\hline $\begin{array}{l}\text { Hoebers } \\
\text { et } \mathrm{al}^{38}\end{array}$ & $\begin{array}{l}\geq 75 \\
<75\end{array}$ & $\begin{array}{l}213 \\
1578 \\
\geq 75 \text { successful } \mathrm{PCl} \\
\mathrm{N}=136 \\
\geq 75 \text { failed } \mathrm{PCl} \\
\mathrm{N}=77\end{array}$ & $\begin{array}{l}63.8 \% \\
69.1 \%\end{array}$ & 5 & $\begin{array}{l}\text { Coronary dissection, } \\
6.7 \% \\
\text { Coronary perforation, } \\
3.3 \%\end{array}$ & $\begin{array}{l}\geq 75 \text { years } \\
\text { MT vs successful } P C l \text { : mortality }(19.6 \% \text { vs } \\
24.6 \%, P=0.13), M A C E(25.8 \% \text { vs } 42.3 \%, \\
P=0.02), M I(I I .5 \% \text { vs } 8.0 \%, P=0.87), C A B G \\
(0 \text { vs } 20.4 \%, P<0.01)\end{array}$ \\
\hline $\begin{array}{l}\text { Tanaka } \\
\text { et } \mathrm{al}^{36}\end{array}$ & $\begin{array}{l}\geq 75 \\
<75\end{array}$ & $\begin{array}{l}67 \\
217 \\
\geq 75 \text { successful } \mathrm{PCl} \\
\mathrm{N}=47 \\
\geq 75 \text { failed } \mathrm{PCl} \\
\mathrm{N}=20\end{array}$ & $\begin{array}{l}77.0 \% \\
79.0 \%\end{array}$ & 3 & $\begin{array}{l}\text { Cerebral infarction, } \\
\text { I.4\% }\end{array}$ & $\begin{array}{l}\geq 75 \text { years } \\
\text { MT vs successful PCl: cardiac survival }(97.6 \% \\
\text { vs } 76.9 \%, P=0.005), \text { MACE-free survival } \\
(64.4 \% \text { vs } 69.2 \%, P=0.02) \text {, TLR-free survival } \\
(85.6 \% \text { vs } 91.7 \%, P=0.52)\end{array}$ \\
\hline
\end{tabular}

Abbreviations: $C A B G$, coronary artery bypass grafting; $\mathrm{Cl}$, confidence interval(s); CTO, chronic total occlusion; HR, hazard ratio; MACE, major adverse cardiovascular events; MI, myocardial infarction; MT, Medical therapy; NA, not applicable; PCl, percutaneous coronary intervention; TLR, target-lesion revascularization; TVR, target-vessel revascularization. 


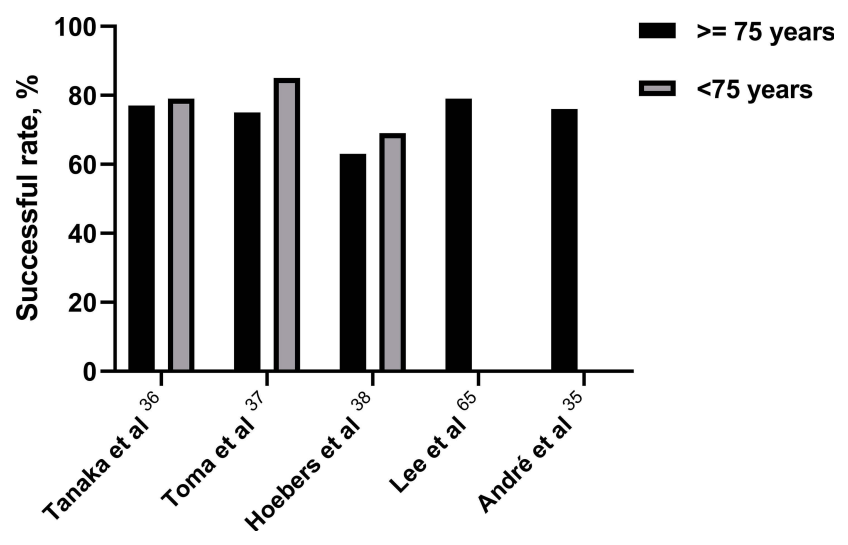

Figure I Successful rates of CTO-PCI in elderly and young patients in recent studies.

Abbreviations: $\mathrm{CTO}$, chronic total occlusion; $\mathrm{PCl}$, percutaneous coronary intervention.

ten randomized trials of 7812 patients to compare the effectiveness of PCI with $\mathrm{CABG}$, and found there was no significant difference in 5.9-year survival rates between the 2 approaches. Patient age modified the treatment's impact on mortality, with HR of 1.25 (0.94-1.66) in patients aged $<55$ years and $0.82(0.70-0.97)$ in patients aged $\geq 65$ ( $P=0.002$ for interaction). CABG was associated with a lower mortality in patients with diabetes and patients aged $\geq 65$ years. ${ }^{48}$ Notably, very few patients aged $\geq 75$ years were enrolled in the trial. In a cohort of 1388 octogenarians (CABG, $\mathrm{n}=441$; PCI, $\mathrm{n}=947$ ) from 2002 to 2008 , Nicolini et al found there were no significant differences in the crude rates of 30-day mortality or in long-term all-caused death rate between CABG and PCI. However, during follow-up, patients in PCI arm had worse outcomes regarding cardiac death, MI, and target vessel revascularization (TVR). The authors also stressed the very few applications of current PCI technology in the study. $^{49}$ In a recent analysis based on 328 patients aged $\geq 75$ years, Flores-Umanzor et al found no significant differences in cardiac death or MI between the PCI and CABG groups. $^{50}$

Older patients may be hospitalized longer after CABG. However, physical, psychological and social recovery were similar with those of younger. ${ }^{51}$ Elderly patients undergoing $\mathrm{CABG}$ are at high risk of low cardiac output syndrome, perioperative MI, stroke, wound infection, renal failure, gastrointestinal complications, respiratory problems, arrhythmia and postoperative delirium. ${ }^{52}$ Cognitive decline and impairment in elderly patients undergoing $\mathrm{CABG}$ is the main concern when compared with PCI. ${ }^{53,54}$ Newman et al evaluated 261 patients who underwent $\mathrm{CABG}$, and found the incidence of cognitive decline was more than $50 \%$ at discharge and $42 \%$ at five years. In addition, cognitive function at discharge was associated with long-term function. ${ }^{55}$

CABG or PCI, which is better for elderly patients with CTOs remains under debate. Although CABG seems to have a slight advantage over PCI for elderly patients with diabetes and complex multivessel disease. However, frequent comorbidities in the elderly can be problematic for CABG surgery, particularly chronic obstructive pulmonary disease and cerebrovascular disease. ${ }^{53}$ Furthermore, the perioperative risk of mortality could increase up to $18.2 \%$ in octogenarians when $\mathrm{CABG}$ is combined with valve surgery. ${ }^{56}$ Remarkable advancements in CTO-PCI technique and equipment have achieved over the past decade, such as dedicated guidewires, microcatheters and the hybrid approach, which enabled high procedural success rates (85-90\%) and maintained acceptable low complications rates $(<3 \%) .^{57,58}$ And these give us more confidence to do more CTO-PCI attempt in elderly CTO patients. Especially when these patients are with higher surgical risk, such as ACS, malignancy, poor mobility, frailty, dementia, and serious comorbidities, which are contraindications of extracorporeal circulation, PCI seems to be more appropriate.

\section{$\mathrm{PCl}$ versus Medical Therapy in Elderly Patients with CTOs}

As mentioned, nearly half of all CTO patients were treated by medical therapy. ${ }^{3,59-61}$ The Trial of Invasive versus Medical Therapy in Elderly Patients with Chronic Symptomatic Coronary Artery Disease (TIME) trial compared PCI with optimal medical therapy in patients aged $\geq 75$ years with chronic stable angina. At 6-month followup, patients in the PCI arm had significant improvements in quality of life and had significant reductions in angina pectoris and MACE (composite risk of death, rehospitalization for ACS and recurrent MI; $19 \%$ vs $49 \%$, $\mathrm{P}<0.001) .{ }^{62}$ Upon 4-year follow-up, there was still a significant reduction in MACE in elderly patients who underwent PCI compared with those who were treated with medical therapy, which was largely driven by the decrease in readmission rates. ${ }^{63}$ Chen et al enrolled 491 patients with ACS and aged $\geq 70$ years, and found PCItreatment was associated with improved 1 and 3-year survival. ${ }^{64}$ Lee et al retrospectively analyzed 311 CTO patients aged $\geq 75$ years to compare the effectiveness of 
medical therapy with revascularization, and demonstrated that the incidence of cardiac death was comparable between groups (HR 1.67; 95\% CI 0.86-3.24, $\mathrm{P}=0.13),{ }^{65}$ consistent with the findings of Guo and his colleagues. ${ }^{66}$ Notable, among the 158 in the revascularization group, 43 patients underwent CABG and 24 patients had a failed PCI, and only $57 \%$ of patients had successful PCI. Additionally, the amount of viable myocardium and ischemia was not assessed, which an estimate of ischemic burden was significantly important when deciding between revascularization and medical therapy in the elderly. ${ }^{67}$ More recently, Flores-Umanzor et al confirmed that, after long-term follow-up, elderly CTO patients receiving conservative treatment had higher all-cause and cardiac mortality compared to patients undergoing revascularization. ${ }^{50}$ Although the Clinical outcomes utilizing revascularization and aggressive Drug evaluation (COURAGE) trial proved that PCI was not associated with reduced the risk of death or other MACE when added to optimal medical therapy in patients with stable CAD, the patients receiving PCI showed significant reduction in ischemia (33\% vs $19 \%$, $\mathrm{P}=0.0004)$, especially in patients with moderate to severe pretreatment ischemia ( $78 \%$ vs $52 \%, \mathrm{P}=0.007)$. Patients with reduced ischemia had lower risk for death or MI (16.2\% vs $32.4 \%, \mathrm{P}=0.08) .{ }^{67}$ The recent DECISIONCTO (Drug-Eluting Stent Implantation Versus Optimal Medical Treatment in Patients with Chronic Total Occlusion) trial and the EuroCTO (Randomized Multicenter Trial to Evaluate the Utilization of Revascularization or Optimal Medical Therapy for the Treatment of Chronic Total Coronary Occlusions) trial showed PCI is not associated with reduction in death, MI, repeated revascularization, major adverse cardiac and cerebrovascular events, and stroke, respectively compared with optimal medical therapy alone. ${ }^{68,69}$ However, patients whose age of $\geq 75$ years are often not well represented in these trials, and these results may not apply to the elderly patients with CTOs.

The European Society of Cardiology indicates that patients with persistent symptoms despite optimized medical therapy and asymptomatic patients with evidence of viability or a high burden of ischemia should be considered for CTO revascularization. ${ }^{70}$ The cost-effectiveness of PCI versus optimal medical therapy, is also an important factor for clinical decision making. In patients with severe symptoms, study showed the cost of CTO-PCI was superior to optimal medical therapy. ${ }^{71}$ Even though, CTOPCI could yield a significantly higher cost-effectiveness ratio by reducing adverse outcomes and improving quality of life as compare to optimal medical therapy.

\section{CTO Procedural Complications in Elderly Patients}

It is known that CTO-PCI has a higher complication rate than non-CTO PCI. Generally speaking, the patients undergoing or the patients who had CTO-PCI required longer fluoroscopy time and greater contrast volume as well as had lower procedural success, when compared with non-CTO PCI. In the NCDR CathPCI registry, CTOPCI had twice the incidence of MACE (1.6\% vs $0.8 \%)$. Interestingly, operator experience was associated with increased success rate and lower rate of MACE in CTOPCI in this study. ${ }^{5}$

Complications were more frequent in the elderly patients. Any procedure-related complications in elderly patients that occur may be potentially lethal. ${ }^{72}$ Elderly patients had more multivessel disease, heavily calcified lesions and diffuse lesions, and these would make the PCI procedure take more fluoroscopy time and greater contrast volume. In addition, severe comorbidities of elderly patients, such as anemia and chronic renal insufficiency, increased risk of major bleeding and contrast-induced nephropathy (CIN). Due to complex lesions, coronary perforation is common in CTO-PCI procedures among elderly patients. Azzalini et al reported patients with perforation were older and had higher Japanese-chronic total occlusion (J-CTO) score. ${ }^{73}$ The retrograde approach was more frequently used, but it was associated with increased risk of perforation compared to an antegrade approach. A recent study also demonstrated a heavier burden of calcification is related to this higher rate of perforation, and coronary perforation rate was higher when CTO procedure fails. ${ }^{74}$ Furthermore, patients with perforation had a higher rate of in-hospital mortality than those without perforation $(5.1 \%$ vs $0.3 \%$ ). However, among 1791 patients observed in the multi-national registry, rates of residual dissection $(6.7 \%$ vs $5.7 \%$ ) and coronary perforation (3.3\% vs 3.4\%) during procedure were comparable between older and younger patients. $^{38}$ The recent global expert consensus of guiding principles for CTO-PCI also reported the availability of dedicated equipment and specific CTO-PCI expertise and volume will help prevent and manage perforation. ${ }^{75}$

The elderly patients are at high risk for CIN. ${ }^{76}$ Previous study reported that the incidence of $\mathrm{CIN}$ in elderly CTO patients underwent PCI was $4.3 \%{ }^{35}$ 
Besides, diabetes, LVEF, presentation with ACS, and contrast volume were independently associated with $\mathrm{CIN}^{77}$ The pathological mechanism of CIN probably due to the increased prevalence of nephrosclerosis in the elderly patients which can cause renal tissue ischemia, decreased number of functional glomeruli, and reduced glomerular filtration rate. ${ }^{78}$ As for achieving renal protection and preventing $\mathrm{CIN}$, the most important measure to reduce the occurrence of CIN is hydration before and after the procedure. ${ }^{79}$ The application of intravascular ultrasound or non-contrast-based optical coherence tomography can lower contrast volume. Furthermore, transradial access can decrease the risk of embolization of atheromatous debris into the renal arteries. ${ }^{79}$

Of these, the most common critical complication of PCI was major bleeding, ${ }^{36}$ and age is an independent predictor of major bleeding after PCI. ${ }^{80}$ The CRUSADE (Can Rapid risk stratification of Unstable angina patients Suppress ADverse outcomes with Early implementation of the ACC/AHA Guidelines) Bleeding Score demonstrated that anemia and lower creatinine clearance which were more common in the elderly, were associated with inhospital major bleeding. ${ }^{81}$ Elderly patients with decreased physical activity have higher levels of activate factors VII, $\mathrm{IX}$, and $\mathrm{X}$, and thrombin-antithrombin complexes in plasma than the young, and platelet reactivity in the body also enhanced in the elderly. ${ }^{82,83}$ These hemostatic changes may increase risk of acute thrombosis. However, on the other hand, secondary to age-related high fibrinolysis, which was active by increasing tissue plasminogen activator levels, reduced thrombus stability and increased the risk of bleeding. ${ }^{84,85}$ The decrease in intestinal absorption, hepatic metabolism, body mass index and the increased adipose tissue in the elderly influence drug distribution and metabolism in the body. ${ }^{86}$ Many antithrombotic drugs, such as low-molecular-weight heparin and glycoprotein IIb/IIIa (GPIIb/IIIa) receptor inhibitors (GPI), often were used in patients undergoing PCI. GPI use was associated with a higher rate of bleeding when compared with no use of a GPI in octogenarians undergoing PCI. ${ }^{87}$ Furthermore, patients with excess dosages of GPI had higher risks for major bleeding as compared to those patients not administered excess dosages (OR, 1.36; 95\% CI, 1.10-1.68). ${ }^{88}$ Kidney drug clearance decreases with age. Gradual decline in kidney function of the elderly affects the clearance of these drug, leading to overdosing of substances, which can increase risk of bleeding. ${ }^{22}$ Periprocedural and postprocedural drug selection and dosage become an important factor of preventing major bleeding in the elderly. In a recent meta-analysis, Lee et al included 11,473 patients from 6 controlled randomized trials, and reported short-term dual antiplatelet therapy (DAPT) was associated with a significant reduction in major bleeding compared with long-term DAPT after DES implantation in elderly patients (HR: 0.46; 95\% CI: 0.24-0.88; $\mathrm{P}=0.0196) .{ }^{89}$ In the SENIOR trail, among elderly patients using DES, a short duration of DAPT could reduce the risk of bleeding events and did not increase of ischemic events (all-cause mortality, MI, stroke, and ischemia-driven target lesion revascularization). ${ }^{90}$ Bivalirudin, a synthetic anticoagulant and as an alternative to unfractionated heparin (UFH), showed comparable efficacy and safety in elderly patients who were at high risk of bleeding and undergoing CTOPCI, and could significantly reduce the risk of bleeding compared with UFH. ${ }^{91}$ In the NCDR CathPCI Registry, Marso et al showed vascular closure devices and bivalirudin were more commonly used and were associated with significantly reduced bleeding rates, especially in elderly patients at high risk of bleeding. ${ }^{92}$ Vascular access of operation also has a great influence on risk of major bleeding. A report including 10,628 nonagenarians from Japanese nationwide registry showed older patients, especially nonagenarians, had a greater risk of in-hospital death and bleeding compared with younger patients after PCI and transradial intervention could reduce the risk bleeding complications in those patients undergoing PCI as compared to transfemoral intervention. ${ }^{93}$ Andre et al also prioritized to radial approach to avoid bleeding. ${ }^{35}$

In summary, even though elderly patients are at a higher risk of bleeding than the young, transradial access, bivalirudin in place of heparin and application of a short duration of DAPT when appropriate could be used to reduce major bleeding complications during CTO-PCI in elderly patients.

\section{The Future of $\mathrm{PCl}$ in Elderly Patients with CTOs}

The guideline and the CRUSADE Quality Improvement Initiative trial showed patients at high risk could get greater benefit from coronary revascularization than patients at low risk. ${ }^{94,95}$ The elderly patients often had more extensive CAD, more severe ischemic burden and higher risk of cardiovascular events than younger patients, and thereby they might greatly benefit from CTO-PCI, 
Table 2 Factors Should Be Considered When CTO-PCI Was Performed in Elderly Patients Based on the Current Literatures

\begin{tabular}{|c|c|c|c|c|c|c|}
\hline $\begin{array}{l}\text { Preoperative } \\
\text { Evaluation }\end{array}$ & $\begin{array}{l}\text { Coronary } \\
\text { Anatomy }\end{array}$ & $\begin{array}{l}\text { Multiple } \\
\text { Comorbidities }\end{array}$ & Hemostasis & $\begin{array}{l}\text { Drug } \\
\text { Metabolism }\end{array}$ & $\begin{array}{l}\text { Drug Selection and } \\
\text { Dosage }\end{array}$ & Others \\
\hline $\begin{array}{l}\text { Angina } \\
\text { symptoms }\end{array}$ & multivessel disease & Frailty & $\begin{array}{l}\text { High levels of } \\
\text { coagulation } \\
\text { factors }\end{array}$ & $\begin{array}{l}\text { Decreased } \\
\text { intestinal } \\
\text { absorption }\end{array}$ & $\begin{array}{l}\text { Bivalirudin in place of } \\
\text { heparin when appropriate }\end{array}$ & $\begin{array}{l}\text { Hydration before } \\
\text { and after the } \\
\text { procedure }\end{array}$ \\
\hline $\begin{array}{l}\text { Viable } \\
\text { myocardium }\end{array}$ & Vessel tortuosity & Anemia & $\begin{array}{l}\text { Enhanced } \\
\text { platelet } \\
\text { reactivity }\end{array}$ & $\begin{array}{l}\text { Reduced } \\
\text { hepatic } \\
\text { metabolism }\end{array}$ & Do not use GPI or use less & Transradial access \\
\hline Ischemia & $\begin{array}{l}\text { Coronary } \\
\text { calcification }\end{array}$ & $\begin{array}{l}\text { Chronic kidney } \\
\text { insufficiency }\end{array}$ & $\begin{array}{l}\text { Enhanced } \\
\text { fibrinolysis }\end{array}$ & $\begin{array}{l}\text { Decreased } \\
\text { renal } \\
\text { clearance }\end{array}$ & $\begin{array}{l}\text { Application of a short } \\
\text { duration of DAPT when } \\
\text { appropriate }\end{array}$ & $\begin{array}{l}\text { Fluoroscopy time } \\
\text { and contrast } \\
\text { volume }\end{array}$ \\
\hline \multirow{2}{*}{$\begin{array}{l}\text { Cost- } \\
\text { effectiveness } \\
\text { ratio }\end{array}$} & Vessel stiffness & $\begin{array}{l}\text { Cerebrovascular } \\
\text { disease }\end{array}$ & & $\begin{array}{l}\text { Increased } \\
\text { adipose tissue }\end{array}$ & & $\begin{array}{l}\text { Vascular closure } \\
\text { devices }\end{array}$ \\
\hline & $\begin{array}{l}\text { Impaired } \\
\text { endothelial repair } \\
\text { following injury }\end{array}$ & $\begin{array}{l}\text { Chronic } \\
\text { pulmonary } \\
\text { disease }\end{array}$ & & & & $\begin{array}{l}\text { Longer } \\
\text { hospitalization }\end{array}$ \\
\hline
\end{tabular}

Abbreviations: CTO, chronic total occlusion; DAPT, dual antiplatelet therapy; GPI, glycoprotein receptor inhibitor; PCI, percutaneous coronary intervention.

known as "treatment-risk paradox", is common in PCI field. ${ }^{96}$ These findings also support the hypothesis that age itself does not represents a contraindication to CTOPCI, which confers a significant benefit particularly in case of extensive CAD and depressed left ventricular function. Dedicated and experienced CTO operators and specialized heart teams should focus on these high-risk patients.

Elderly CTO patients should be focused on and inclusion criteria to include real world patients should be expanded in future clinical trials and studies. Interventional cardiologists should also consider the effects of elderly patient frailty, comorbidities and bleeding risk on PCI outcomes. Risk stratification and a holistic assessment should be done before CTO-PCI. Table 2 summarize factors that should be considered when CTO-PCI was performed in elderly patients based on the current literature.

With increasing age, the goal and importance of treating heart disease, especially CAD, have shifted from prolonging life to improving health status and quality of life and maintaining independence. Ischemic symptom improvement is the primary indication for CTO-PCI. Recent advances in CTO-PCI equipment and techniques, such as dedicated guidewires, microcatheters, antegrade dissection reentry, retrograde techniques and hybrid CTO algorithm, have made the procedures that elderly patients underwent were as safe and effective to improve patient outcomes as those in younger patients. CTO-PCI should not be avoided based on age alone, and the subset of elderly CTO patients will gain some benefit from intervention. Because the proportion of elderly people is growing worldwide, the review focus on this high-risk subset of patients may be particularly meaningful.

\section{Conclusion}

Accordingly, with the latest refinements equipment and techniques, similar success rates in elderly and young patients, it is safe and effective when performed in highvolume CTO-PCI centers and by experienced operators, and may be actively considered as a treatment option for elderly CTO patients to achieve complete myocardial revascularization. Well-designed, large randomized clinical trials compared PCI with DES, optimal medical therapy, and CABG for the management of elderly CTO patients are warranted.

\section{Disclosure}

The authors report no conflicts of interest in this work.

\section{References}

1. Sianos G, Werner GS, Galassi AR, et al. Recanalisation of chronic total coronary occlusions: 2012 consensus document from the EuroCTO club. EuroIntervention. 2012;8(1):139-145. doi:10.4244/ EIJV8I1A21

2. Guo L, Zhang SF, Wu J, et al. Successful recanalisation of coronary chronic total occlusions is not associated with improved cardiovascular survival compared with initial medical therapy. Scand Cardiovasc J. 2019;53(6):305-311. 
3. Fefer P, Knudtson ML, Cheema AN, et al. Current perspectives on coronary chronic total occlusions: the Canadian Multicenter Chronic Total Occlusions registry. J Am Coll Cardiol. 2012;59 (11):991-997.

4. Pristipino C, Granatelli A, Capasso M, et al. Effects of reperfusion obtained two to six months after acute myocardial infarction on myocardial electrical stabilization in patients with an occluded infarct-related coronary artery. Am J Cardiol. 2005;96(6):769-772.

5. Brilakis ES, Banerjee S, Karmpaliotis D, et al. Procedural outcomes of chronic total occlusion percutaneous coronary intervention: a report from the NCDR (National CardiovascularData Registry). JACC Cardiovasc Interv. 2015;8(2):245-253.

6. Galassi AR, Tomasello SD, Reifart N, Werner GS, Sianos G. Inhospital outcomes of percutaneous coronary intervention in patients with chronic total occlusion: insights from the ERCTO (European Registry of Chronic Total Occlusion) registry. EuroIntervention. 2011;7(4):472-479.

7. Konstantinidis NV, Sofidis G, Kolettas V, Karvounis H, Sianos G. Bifurcation CTO recanalization with contemporary antegrade and retrograde techniques in a patient with two chronically occluded coronary arteries. Hellenic J Cardiol. 2016;57(5):371-374.

8. Guo L, Lv HC, Zhong L, et al. Gender differences in long-term outcomes of medical therapy and successful percutaneous coronary intervention for coronary chronic total occlusions. J Interv Cardiol. 2019. doi:10.1155/2019/2017958

9. Maeremans J, Walsh S, Knaapen P, et al. The hybrid algorithm for treating chronic total occlusions in Europe: the recharge registry. J Am Coll Cardiol. 2016;68(18):1958-1970.

10. Formiga F, Ferrer A, Sanz H, et al. Patterns of comorbidity and multimorbidity in the oldest old: the Octabaix study. Eur J Intern Med. 2013;24(1):40-44. doi:10.1016/j.ejim.2012.11.003

11. Cohen HA, Williams DO, Holmes DR Jr, et al. Impact of age on procedural and 1-year outcome in percutaneous transluminal coronary angioplasty: a report from the NHLBI Dynamic Registry. Am Heart J. 2003;146(3):513-519. doi:10.1016/S0002-8703(03)00259-X

12. Levine GN, Bates ER, Blankenship JC, et al. 2011 ACCF/AHA/ SCAI guideline for percutaneous coronary intervention: a report of the american college of cardiology foundation/american heart association task force on practice guidelines and the society for cardiovascular angiography and interventions. Circulation. 2011;124(23): e574-651. doi:10.1161/CIR.0b013e31823ba622

13. Zhang $\mathrm{H} \mathrm{P,} \mathrm{Ai} \mathrm{H,} \mathrm{Zhao} \mathrm{Y,} \mathrm{et} \mathrm{al.} \mathrm{Effect} \mathrm{of} \mathrm{chronic} \mathrm{total} \mathrm{occlusion}$ percutaneous coronary intervention on clinical outcomes in elderly patients. Am J Med Sci. 2018;355(2):174-182. doi:10.1016/j. amjms.2017.09.007

14. Rosengren A, Wallentin L, Simoons M, et al. Age, clinical presentation, and outcome of acute coronary syndromes in the Euroheart acute coronary syndrome survey. Eur Heart J. 2006;27(7):789-795.

15. Sheifer SE, Rathore SS, Gersh BJ, et al. Time to presentation with acute myocardial infarction in the elderly: associations with race, sex, and socioeconomic characteristics. Circulation. 2000;102(14): 1651-1656.

16. Wennberg DE, Makenka DJ, Sengupta A, et al. Percutaneous transluminal coronary angioplasty in the elderly: epidemiology, clinical risk factors, and in-hospital outcomes. The Northern New England cardiovascular disease study group. Am Heart J. 1999;137(4 Pt 1):639-645.

17. Batchelor WB, Anstrom KJ, Muhlbaier LH, et al. Contemporary outcome trends in the elderly undergoing percutaneous coronary interventions: results in 7472 octogenarians. J Am Coll Cardiol. 2000;36(3):723-730

18. Kelsey SF, Miller DP, Holubkov R, et al. Results of percutaneous transluminal coronary angioplasty in patients greater than or equal to 65 years of age (from the 1985 to 1986 National Heart, Lung, and Blood Institute's Coronary Angioplasty Registry). Am J Cardiol. 1990;66(15):1033-1038.
19. Behan M, Dixon G, Haworth P. PCI in octogenarians: our centre 'real world'experience. Age Ageing. 2009;38(4):469-473.

20. Hsu JT, Kyo E, Chu CM, Tsuji T, Watanabe S. Impact of calcification length ratio on the intervention for chronic total occlusions. Int J Cardiol. 2011;150(2):135-141.

21. Newman AB, Naydeck BL, Sutton-Tyrrell K, Feldman A, Edmundowicz D, Kuller LH. Coronary artery calcification in older adults to age 99: prevalence and risk factors. Circulation. 2001;104 (22):2679-2684

22. Wang TY, Gutierrez A, Peterson ED. Percutaneous coronary intervention in the elderly. Nat Rev Cardiol. 2011;8(2):79-90.

23. Moser DK, Kimble LP, Alberts MJ, et al. Reducing delay in seeking treatment by patients with acute coronary syndrome and stroke: a scientific statement from the American Heart Association Council on cardiovascular nursing and stroke council. Circulation. 2006;114 (2):168-182.

24. Fried LP, Tangen CM, Walston J, et al. Frailty in older adults: evidence for a phenotype. J Gerontol a Biol Sci Med Sci. 2001;56 (3):M146-156.

25. Gharacholou SM, Roger VL, Lennon RJ, et al. Comparison of frail patients versus nonfrail patients $\geq 65$ years of age undergoing percutaneous coronary intervention. Am J Cardiol. 2012;109(11):1569-1575.

26. Mitnitski AB, Graham JE, Mogilner AJ, Rockwood K. Frailty, fitness and late-life mortality in relation to chronological and biological age. BMC Geriatr. 2002;2:1.

27. Sanchez E, Vidan MT, Serra JA, Fernandez-Aviles F, Bueno H. Prevalence of geriatric syndromes and impact on clinical and functional outcomes in older patients with acute cardiac diseases. Heart. 2011;97(19):1602-1606.

28. Studenski S, Perera S, Patel K, et al. Gait speed and survival in older adults. JAMA. 2011;305(1):50-58.

29. Ling CH, Taekema D, de Craen AJ, Gussekloo J, Westendorp RG, Maier AB. Handgrip strength and mortality in the oldest old population: the Leiden 85-plus study. CMAJ. 2010;182(5):429-435.

30. Shanmugasundaram M. Percutaneous coronary intervention in elderly patients: is it beneficial? Tex Heart Inst J. 2011;38(4):398-403.

31. Becker RC. Thrombotic preparedness in aging: a translatable construct for thrombophilias? J Thromb Thrombolysis. 2007;24(3):323-325.

32. Claessen BE, Dangas GD, Weisz G, et al. Prognostic impact of a chronic total occlusion in a non-infarct-related artery in patients with ST-segment elevation myocardial infarction: 3-year results from the HORIZONS-AMI trial. Eur Heart J. 2012;33(6):768-775.

33. Olivari Z, Rubartelli P, Piscione F, et al. Immediate results and one-year clinical outcome after percutaneous coronary interventions in chronic total occlusions: data from a multicenter, prospective, observational study (TOAST-GISE). J Am Coll Cardiol. 2003;41(10):1672-1678.

34. Dinenno FA, Jones PP, Seals DR, Tanaka H. Limb blood flow and vascular conductance are reduced with age in healthy humans: relation to elevations in sympathetic nerve activity and declines in oxygen demand. Circulation. 1999;100(2):164-170.

35. Andre R, Dumonteil N, Lhermusier T, et al. In-hospital and long-term outcomes after percutaneous coronary intervention for chronic total occlusion in elderly patients: a consecutive, prospective, single-centre study. Arch Cardiovasc Dis. 2016;109(1):13-21.

36. Tanaka Y, Takeshita S, Takahashi S, et al. Comparison of short- and long-term outcomes of percutaneous coronary intervention for chronic total occlusions between patients aged $\geq 75$ years and those aged <75 years. Am J Cardiol. 2013;112(6):761-766.

37. Toma A, Gebhard C, Gick M, et al. Survival after percutaneous coronary intervention for chronic total occlusion in elderly patients. EuroIntervention. 2017;13(2):e228-e235.

38. Hoebers LP, Claessen BE, Dangas GD, et al. Long-term clinical outcomes after percutaneous coronary intervention for chronic total occlusions in elderly patients ( $\geq 75$ years): five-year outcomes from a 1791 patient multi-national registry. Catheter Cardiovasc Interv. 2013;82(1):85-92. 
39. Morino Y, Kimura T, Hayashi Y, et al. In-hospital outcomes of contemporary percutaneous coronary intervention in patients with chronic total occlusion: insight from the J-CTO Registry (Multicenter CTO Registry in Japan). JACC Cardiovasc Interv. 2010;3(2):143-151.

40. Garcia S, Sandoval Y, Roukoz H, et al. Outcomes after complete versus incomplete revascularization of patients with multivessel coronary artery disease: a meta-analysis of 89,883 patients enrolled in randomized clinical trials and observational studies. $\mathrm{J} \mathrm{Am} \mathrm{Coll}$ Cardiol. 2013;62(16):1421-1431.

41. Kappetein AP, Feldman TE, Mack MJ, et al. Comparison of coronary bypass surgery with drug-eluting stenting for the treatment of left main and/or three-vessel disease: 3-year follow-up of the SYNTAX trial. Eur Heart J. 2011;32(17):2125-2134.

42. Hannan EL, Racz M, Holmes DR, et al. Impact of completeness of percutaneous coronary intervention revascularization on long-term outcomes in the stent era. Circulation. 2006;113(20):2406-2412.

43. Head SJ, Milojevic M, Daemen J, et al. Mortality after coronary artery bypass grafting versus percutaneous coronary intervention with stenting for coronary artery disease: a pooled analysis of individual patient data. Lancet. 2018;391(10124):939-948.

44. Farkouh ME, Domanski M, Sleeper LA, et al. Strategies for multivessel revascularization in patients with diabetes. $N$ Engl J Med. 2012;367(25):2375-2384.

45. Wilson MF, Baig MK, Ashraf H. Quality of life in octagenarians after coronary artery bypass grafting. Am J Cardiol. 2005;95(6):761-764.

46. McKellar SH, Brown ML, Frye RL, Schaff HV, Sundt TM 3rd. Comparison of coronary revascularization procedures in octogenarians: a systematic review and meta-analysis. Nat Clin Pract Cardiovasc Med. 2008;5(11):738-746.

47. Hannan EL, Zhong Y, Berger PB, et al. Comparison of intermediate-term outcomes of coronary artery bypass grafting versus drug-eluting stents for patients $\geq 75$ years of age. Am J Cardiol. 2014;113(5):803-808.

48. Hlatky MA, Boothroyd DB, Bravata DM, et al. Coronary artery bypass surgery compared with percutaneous coronary interventions for multivessel disease: a collaborative analysis of individual patient data from ten randomised trials. Lancet. 2009;373(9670):1190-1197.

49. Nicolini F, Contini GA, Fortuna D, et al. Coronary artery surgery versus percutaneous coronary intervention in octogenarians: long-term results. Ann Thorac Surg. 2015;99(2):567-574.

50. Flores-Umanzor EJ, Vazquez S, Cepas-Guillen P, et al. Impact of revascularization versus medical therapy alone for chronic total occlusion management in older patients. Catheter Cardiovasc Interv. 2019;94(4):527-535.

51. Artinian NT, Duggan C, Miller P. Age differences in patient recovery patterns following coronary artery bypass surgery. Am J Crit Care. 1993;2(6):453-461.

52. Rocha AS, Pittella FJ, Lorenzo AR, et al. Age influences outcomes in 70-year or older patients undergoing isolated coronary artery bypass graft surgery. Rev Bras Cir Cardiovasc. 2012;27(1):45-51.

53. Kaehler J, Meinertz T, Hamm CW. Coronary interventions in the elderly. Heart. 2006;92(8):1167-1171.

54. Natarajan A, Samadian S, Clark S. Coronary artery bypass surgery in elderly people. Postgrad Med J. 2007;83(977):154-158.

55. Newman MF, Kirchner JL, Phillips-Bute B, et al. Longitudinal assessment of neurocognitive function after coronary-artery bypass surgery. N Engl J Med. 2001;344(6):395-402.

56. Alexander KP, Anstrom KJ, Muhlbaier LH, et al. Outcomes of cardiac surgery in patients $>$ or $=80$ years: results from the National Cardiovascular Network. J Am Coll Cardiol. 2000;35(3):731-738.

57. Brilakis ES, Grantham JA, Rinfret S, et al. A percutaneous treatment algorithm for crossing coronary chronic total occlusions. JACC Cardiovasc Interv. 2012;5(4):367-379.

58. Tajti P, Karmpaliotis D, Alaswad K, et al. The hybrid approach to chronic total occlusion percutaneous coronary intervention: update from the PROGRESS CTO Registry. JACC Cardiovasc Interv. 2018;11(14):1325-1335.
59. Guo L, Wu J, Zhong L, et al. Two-year clinical outcomes of medical therapy vs. revascularization for patients with coronary chronic total occlusion. Hellenic J Cardiol. 2019. doi:10.1016/j.hjc.2019.03.006

60. Guo L, Zhong L, Chen K, Wu J, Huang RC. Long-term clinical outcomes of optimal medical therapy vs. successful percutaneous coronary intervention for patients with coronary chronic total occlusions. Hellenic J Cardiol. 2018;59(5):281-287.

61. Tomasello SD, Boukhris M, Giubilato S, et al. Management strategies in patients affected by chronic total occlusions: results from the Italian Registry of Chronic Total Occlusions. Eur Heart J. 2015;36 (45):3189-3198.

62. Investigators TIME. Trial of invasive versus medical therapy in elderly patients with chronic symptomatic coronary-artery disease (TIME): a randomised trial. Lancet. 2001;358(9286):951-957.

63. Pfisterer M. Trial of Invasive versus medical therapy in elderly patients investigators. Long-term outcome in elderly patients with chronic angina managed invasively versus by optimized medical therapy: four-year follow-up of the randomized trial of invasive versus medical therapy in elderly patients (TIME). Circulation. 2004;110(10):1213-1218.

64. Chen X, Barywani SB, Sigurjonsdottir R, Fu M. Improved short and long term survival associated with percutaneous coronary intervention in the elderly patients with acute coronary syndrome. $B M C$ Geriatr. 2018;18(1):137.

65. Lee SH, Yang JH, Choi SH, et al. Long-term clinical outcomes of medical therapy for coronary chronic total occlusions in elderly patients ( $\geq 75$ years). Circ J. 2015;79(8):1780-1786.

66. Guo L, Lv HC, Zhong L, et al. Comparison of long-term outcomes of medical therapy and successful recanalisation for coronary chronic total occlusions in elderly patients: a report of 1294 patients. Cardiovasc Diagn Ther. 2019;9(6):586-595.

67. Shaw LJ, Berman DS, Maron DJ, et al. Optimal medical therapy with or without percutaneous coronary intervention to reduce ischemic burden: results from the Clinical Outcomes Utilizing Revascularization and Aggressive Drug Evaluation (COURAGE) trial nuclear substudy. Circulation. 2008;117(10):1283-1291.

68. Werner GS, Martin-Yuste V, Hildick-Smith D, et al. A randomized multicentre trial to compare revascularization with optimal medical therapy for the treatment of chronic total coronary occlusions. Eur Heart J. 2018;39(26):2484-2493.

69. Lee SW, Lee PH, Ahn JM, et al. Randomized trial evaluating percutaneous coronary intervention for the treatment of chronic total occlusion. Circulation. 2019;139(14):1674-1683.

70. Neumann FJ, Sousa-Uva M, Ahlsson A, et al. 2018 ESC/EACTS guidelines on myocardial revascularization. Eur Heart J. 2019;40 (2):87-165.

71. Gada H, Whitlow PL, Marwick TH. Establishing the cost-effectiveness of percutaneous coronary intervention for chronic total occlusion in stable angina: a decision-analytic model. Heart. 2012;98(24):1790-1797.

72. De Gregorio J, Kobayashi Y, Albiero R, et al. Coronary artery stenting in the elderly: short-term outcome and long-term angiographic and clinical follow-up. J Am Coll Cardiol. 1998;32(3):577-583.

73. Azzalini L, Poletti E, Ayoub M, et al. Coronary artery perforation during chronic total occlusion percutaneous coronary intervention: epidemiology, mechanisms, management, and outcomes. EuroIntervention. 2019;15(9):e804-e811.

74. Cheney A, Kearney KE, Lombardi W. Sex-based differences in chronic total occlusion management. Curr Atheroscler Rep. 2018;20 (12):60.

75. Brilakis ES, Mashayekhi K, Tsuchikane E, et al. Guiding principles for chronic total occlusion percutaneous coronary intervention. Circulation. 2019;140(5):420-433.

76. Rear R, Bell RM, Hausenloy DJ. Contrast-induced nephropathy following angiography and cardiac interventions. Heart. 2016;102 (8):638-648. 
77. Azzalini L, Poletti E, Lombardo F, et al. Risk of contrast-induced nephropathy in patients undergoing complex percutaneous coronary intervention. Int J Cardiol. 2019;290:59-63.

78. Denic A, Glassock RJ, Rule AD. Structural and functional changes with the aging kidney. Adv Chronic Kidney Dis. 2016;23(1):19-28.

79. Almendarez M, Gurm HS, Mariani J Jr, et al. Procedural strategies to reduce the incidence of contrast-induced acute kidney injury during percutaneous coronary intervention. JACC Cardiovasc Interv. 2019;12(19):1877-1888

80. Montalescot G, White HD, Gallo R, et al. Enoxaparin versus unfractionated heparin in elective percutaneous coronary intervention. N Engl J Med. 2006;355(10):1006-1017.

81. Subherwal S, Bach RG, Chen AY, et al. Baseline risk of major bleeding in non-ST-segment-elevation myocardial infarction: the CRUSADE (Can Rapid risk stratification of Unstable angina patients Suppress ADverse outcomes with Early implementation of the ACC/AHA guidelines) bleeding score. Circulation. 2009;119(14):1873-1882.

82. Mari D, Mannucci PM, Coppola R, Bottasso B, Bauer KA, Rosenberg RD. Hypercoagulability in centenarians: the paradox of successful aging. Blood. 1995;85(11):3144-3149.

83. Zahavi J, Jones NA, Leyton J, Dubiel M, Kakkar VV. Enhanced in vivo platelet "release reaction" in old healthy individuals. Thromb Res. 1980;17(3-4):329-336.

84. Lakatta EG. Arterial and cardiac aging: major shareholders in cardiovascular disease enterprises: part III: cellular and molecular clues to heart and arterial aging. Circulation. 2003;107(3):490-497.

85. Knight CJ, Panesar M, Wright C, et al. Altered platelet function detected by flow cytometry: effects of coronary artery disease and age. Arterioscler Thromb Vasc Biol. 1997;17(10):2044-2053.

86. Rioboo-Leston L, Raposeiras-Roubin S, Abu-Assi E, Iniguez-Romo A. Bleeding risk assessment in elderly patients with acute coronary syndrome. J Geriatr Cardiol. 2019;16(2):145-150.

87. Sadeghi HM, Grines CL, Chandra HR, et al. Percutaneous coronary interventions in octogenarians. glycoprotein $\mathrm{IIb} / \mathrm{III}$ a receptor inhibitors' safety profile. J Am Coll Cardiol. 2003;42(3):428-432.

88. Alexander KP, Chen AY, Roe MT, et al. Excess dosing of antiplatelet and antithrombin agents in the treatment of non-ST-segment elevation acute coronary syndromes. JAMA. 2005;294(24):3108-3116.
89. Lee SY, Hong MK, Palmerini T, et al. Short-term versus long-term dual antiplatelet therapy after drug-eluting stent implantation in elderly patients: a meta-analysis of individual participant data from 6 randomized trials. JACC Cardiovasc Interv. 2018;11(5):435-443.

90. Varenne O, Cook S, Sideris G, et al. Drug-eluting stents in elderly patients with coronary artery disease (SENIOR): a randomised single-blind trial. Lancet. 2018;391(10115):41-50.

91. Wang Y, Zhao HW, Wang CF, et al. Efficacy and safety of bivalirudin during percutaneous coronary intervention in high-bleeding-risk elderly patients with chronic total occlusion: a prospective randomized controlled trial. Catheter Cardiovasc Interv. 2019;93 (S1):825-831.

92. Marso SP, Amin AP, House JA, et al. Association between use of bleeding avoidance strategies and risk of periprocedural bleeding among patients undergoing percutaneous coronary intervention. JAMA. 2010;303(21):2156-2164.

93. Numasawa $\mathrm{Y}$, Inohara $\mathrm{T}$, Ishii $\mathrm{H}$, et al. Comparison of outcomes after percutaneous coronary intervention in elderly patients, including 10 628 nonagenarians: insights from a Japanese Nationwide Registry (JPCI registry). J Am Heart Assoc. 2019;8(5):e011183.

94. Anderson JL, Adams CD, Antman EM, et al. 2012 ACCF/AHA focused update incorporated into the ACCF/AHA 2007 guidelines for the management of patients with unstable angina/non-STelevation myocardial infarction: a report of the American College of Cardiology Foundation/American Heart Association task force on practice guidelines. J Am Coll Cardiol. 2013;61(23):e179-347.

95. Bhatt DL, Roe MT, Peterson ED, et al. Utilization of early invasive management strategies for high-risk patients with non-ST-segment elevation acute coronary syndromes: results from the CRUSADE Quality Improvement Initiative. JAMA. 2004;292(17):2096-2104.

96. Iglesias JF, Degrauwe S, Rigamonti F, Noble S, Roffi M. Percutaneous coronary intervention of chronic total occlusions in patients with diabetes mellitus: a treatment-risk paradox. Curr Cardiol Rep. 2019;21(2):9.
Clinical Interventions in Aging

\section{Publish your work in this journal}

Clinical Interventions in Aging is an international, peer-reviewed journal focusing on evidence-based reports on the value or lack thereof of treatments intended to prevent or delay the onset of maladaptive correlates of aging in human beings. This journal is indexed on PubMed Central, MedLine, CAS, Scopus and the Elsevier

\section{Dovepress}

Bibliographic databases. The manuscript management system is completely online and includes a very quick and fair peer-review system, which is all easy to use. Visit http://www.dovepress.com/ testimonials.php to read real quotes from published authors. 